\title{
P1004
}

\section{化学物質曝露に関するリスクアセスメント方法の評価 一仮想事例を利用したコントロールバンディング法の評価}

\author{
今井 順一 1 、橋本 晴男 ${ }^{2}$ 後藤 敏明 2 、仲地 脩豊 ${ }^{2}$ 鈴木 英孝 ${ }^{2} 、$ 梶木 繁之 ${ }^{1} 、$ \\ 森 晃爾 ${ }^{1}$ \\ 産業医科大学 産業医実務研修センター、エソンモービル(有) 医務産業衛生部
}

【はじめに】現在の産業界に扔いて 5 万種類以上も の化学物質が使用されているが、そのうち法令で 管理が義務付けられている物質は限られており、 今後は自主的な化学物質管理が各企業に求められ る。そこでは多様な化学物質の使用に伴う健康り スクを評価するための適切なリスクアセスメント 手法が必要となる。本研究では、簡易的な方法であ り現在世界的に徐々に使用が広まりつつあるコン トロールバンディング法（以下 CB 法）を用いて、 有機溶剂を取扱う一般的な作業およびその作業中 で使用頻度が比較的高いと思われる物質を仮想 し、CB 法で導かれる必要な管理手法の評価を実施 した。その結果について報告抢よび考察する。

【方法】一般的な作業としてドライクリーニング業 （テトラクロロエチレン、1,1,1トリクロロエタン、 ターペン)、研究施設内での作業 (アセトン、二硫 化水素、ジメチルホルムアミド)、塗装業 (トルエ ン、キシレン、ジメチルエーテル)を仮想し、これ らの各作業・各物質について、英国 HSEのホーム ページ上のCB法ツール(COSHH Essentials)を 用いてリスク評価を行った。

【結果】今回行った仮想評価の結果は表の通りで あった。な打、推奨される管理ガイダンスの解釈 は、100 番代 $\Rightarrow$ 全体換気、200 番代 $\Rightarrow$ 局所換気、300
番代 $\Rightarrow$ 密閉化、400 番代 $\Rightarrow$ 個別対策（専門化へ相 談）である。また、S100 番代は皮膚・眼の暴露防 止、保護具などの対策である。

【考察】評価の結果、特定の物質は作業設備・場所 (屋内外等)・作業時間等を問わず、個別対応 (専門 家へ相談)が必要との結果になった。また局所排気 や密閉化等の対策が妥当と判定された場合でも、 指示内容に過剩対応感が強く、費用等の関係で管 理ガイダンスに従わない場合もあるものと予想さ れる。CB 法で示された結果をより安易な対応に変 更して行う際には、専門家の関与により、変更後の 管理方法の妥当性の評価が重要であると思われ る。また、使用する化学物質を変更することで作業 がより安全になることを、CB法を用いることに よって確認できることが示された。このように、 $\mathrm{CB}$ 法憻入予定化学物質の安全性スクリーニン グ等に有用であるが、適切な利用には専門家の支 援が必要と考えられる。今後は、化学物質管理に習 熟した専門家の養成や $\mathrm{CB}$ 法の特徵を生かした包 括的な化学物質のリスク管理マニュアル等の導入 必要であると思われる。更に多くの作業や化学物 質について評価を行い、実用性と課題の検討を行 う予定である。

\begin{tabular}{|c|c|c|c|c|}
\hline 答勈名 & $\|$ task & 间年 & T直结栍 & 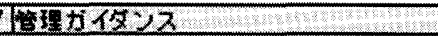 \\
\hline \multirow[b]{3}{*}{$H=\langle 2 U 1)=22$} & \multirow[b]{3}{*}{ donine } & 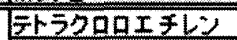 & 0 & 6400 \\
\hline & & HyonaIs & $\bar{D}$ & $5400,5100,5101$ \\
\hline & & $\sqrt{2-\infty}$ & $\bar{c}$ & $6200,6202,6228,6229,5100,5101$ \\
\hline \multirow[b]{3}{*}{ 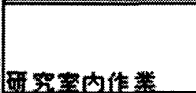 } & \multirow[b]{3}{*}{ ldiopine } & Ptry & $\bar{A}$ & 6100.5100 .5101 \\
\hline & & 三势化笑羔 & D & $6300,6301,5100,5101$ \\
\hline & & OXチルホルムアミF & $\bar{D}$ & $6200,6201.6203 .5100 .5101$ \\
\hline \multirow[b]{3}{*}{ 㾣装 } & \multirow[b]{3}{*}{ Surface coatine } & HWIY & $\bar{D}$ & $9400,5100,5101$ \\
\hline & & キシレン & $\overline{\mathbf{B}}$ & $6200,6202,6221,5100,5101$ \\
\hline & & オルマルヘキサン & $\overline{\mathrm{D}}$ & $6400.5100,5101$ \\
\hline
\end{tabular}

